\title{
Will we all be Rooned without a Desal Plant? Hanrahan's Lament and the Problem of Urban Water Planning under Climate Change
}

\author{
Donna Brennan ${ }^{1}$
}

\begin{abstract}
Given the uncertainty of climate forecasts there is a danger of overly pessimistic forecasts justifying overly large and early investment in desalination plants. If the recent weather patterns turn out to be just a drought, water utilities will find themselves with redundant desalination plants or, worse still, a commitment to pay high costs to desalinate water when dams are regularly spilling. A case study of Western Australia argues that the construction of the touted second desalination plant will mean dams will spill significantly one year in two if the climate follows the average patter of the years 1975-2006. Further, the climate assumptions that are used to justify the plant imply a long-run cost potentially high enough to eliminate the demand for the water supplied by the plant.
\end{abstract}

\section{Introduction}

'If rain don't come this month,' said Dan,

And cleared his throat to speak -

'We'll all be rooned,' said Hanrahan,

'If rain don't come this week.'

'If we don't get three inches, man,

Or four to break this drought,

We'll be rooned,' said Hanrahan,

'Before this year is out.'

Said Hanrahan, J O'Brien, 1921

O'Brien's poem tells the story of a very pessimistic farmer whose obsession with the weather was probably understandable, given that his cropping fortune depended on getting the right quantity of seasonal rainfall at the right time. For managers of public water utilities and their responsible ministers, the stakes of the rainfall gamble are also very high. They take the blame when a city runs short of water in a country where urban water supply seems to be a matter of

\footnotetext{
${ }^{1}$ Centre for Agricultural Policy, Institute for Policy and Strategy for Agriculture and, Vietnam, donnabrennan@iinet.net.au
} 
politics rather than of economics. The difference, however, between Hanrahan's situation and that faced in the public water sector is that utilities can now take action to protect themselves from the vagaries of the weather by investing in desalination, a climate-independent technology. Unfortunately, there is little to protect society from the Hanrahanian pessimism that seems to be ingrained in those who have a stake in the Australian weather. As Hanrahan found out soon enough, too much rainfall can lead to ruin too:

...In God's good time down came the rain...

$\ldots$ and every creek a banker ran

And dams filled over top.

'We'll all be rooned,' said Hanrahan

'If this rain doesn't stop.'

The rainfall probability distribution also poses substantial risk to investors in desalination technology. Cooley et al. (2006) report the case of a desalination plant built in Santa Barbara, California, in response to a prolonged drought, that was shut down shortly after it began operation because the drought broke and it was deemed too expensive to run compared to conventional supplies. In the two weeks prior to the announcement of the successful contractor for construction of Sydney's 80 gigalitre (GL) per annum desalination plant, heavy rains had recharged Sydney's dams by 328GL (two-thirds of annual consumption). In this case, no change was made to the construction schedule on the grounds that the desalination plant was still justified to compensate for a reduction in rainfall associated with climate change. However, it remains to be seen how palatable the high costs of running the desalination plant will be if Warrangamba dam is full when the plant is completed.

The trade-off between the cost of supply failure if it doesn't rain, compared to the financial burden of redundancy if it does, has economic and political dimensions. A large proportion of urban water demand in Australia is used outdoors and the strategy for addressing short-term supply failure has been to impose restrictions on outdoor use. Water restrictions impose a welfare cost on the consumer, such as a loss of utility from outdoor gardens and the time cost of hand-watering. Based on decisions made in Western Australia in recent years, the perceived political costs of urban water restrictions are substantially higher than this. Whilst there is an argument for reserve capacity as an insurance policy where there is a perceived high cost of failure, there has been no scrutiny of supply-augmentation decisions made by planners regarding the economic trade-off of augmentation vs. supply failure.

In days past it would have been possible to measure the perceived value of supply failure by comparing expenditure on system capacity against the probability that failure will occur; but this is no longer possible because the probability of rainfall outcomes can no longer be securely based on the historical 
climatic record. Thus the 'climate change' issue seems to present an opportunity for Hanrahan's descendents to assume whatever they like about the future catchment yield, so making it is possible to justify substantial investment in desalination technology that may have questionable economic foundations. In Victoria, the calculations for the desalination plant there are based on future catchment yield being defined by the mean of the previous three years (Department of Sustainability and the Environment 2007). In Perth, the Water Corporation recently changed the historical period used to assess future system yield from a nine-year (1997-2005) average to a six-year (2001-06) average, arbitrarily dropping the wettest year in recent history (2000) and adding the driest (2006), thus ensuring an additional 23GL 'shortfall' in the yield of the conventional sources.

Even if political processes deem that an ultra-conservative, ruler-and-pen approach to forecasting the climate is acceptable, there is an economic-efficiency problem if the assumption is not applied consistently across water management. If it is reasonable to assume that the current drought will last forever, then the implications for 'long-run marginal cost', and thus efficient water pricing, are substantial: for even though urban water demand is relatively inelastic, the extent of the price increase rationally necessitated by climate change may reduce demand sufficiently to make the rush of current desalination construction planning across the country surplus to requirements. If only the economic regulators would adopt the same climate forecasts as the water utilities!

This paper presents an analysis of these issues using a case study of the proposed second desalination plant to be built in Western Australia, at Binningup. The aim of the paper is to highlight the need for more rigour and more consistency in the planning and pricing of urban water, especially given the prospect of climate change. The next section provides a brief overview of the climate situation in Western Australia. The magnitude of uncertainty regarding climate and catchment yield and its implications for urban water-supply planning are then demonstrated using a simple balance sheet of water supply and demand under current institutional arrangements. A more rigorous assessment of system yield and risk of supply failure is then presented, which demonstrates the relationship between assumptions about the probability-distribution of catchment yield, the timing of supply augmentation, and the cost of supplying urban water over the medium term. There is no attempt in the paper to provide a complete economic analysis of the problem, because of lack of information on the economic cost of supply failure. However, the long-run marginal-cost implications associated with these climate and supply-augmentation assumptions are calculated and compared to prices currently paid by consumers. 


\section{Predicting the climate}

Climate-change scientists have forecast a gloomy outlook for rainfall and Perth metropolitan water supplies in the $21^{\text {st }}$ century. A reduction in annual rainfall of up to 20 per cent by 2030 is predicted in the south-west of Australia, compared to a maximum reduction of 10 per cent in the eastern states; and Perth urban water supplies face greater insecurity (Pittock 2003). In 1998 the WA government set up the Indian Ocean Climate Initiative (IOCI), a collaboration between the CSIRO, the Bureau of Meteorology and Western Australian government agencies to assess climate-change issues facing south Western Australia, and provide interpretation of, and judgment on, the uncertainties surrounding climate-change science. This group has developed models to downscale the results of global climate-change models to the weather patterns of the south-west of Western Australia and to forecast the impact on surface-water inflows into metropolitan dams. The downscaled rainfall models have been shown to fit well to the post-1975 rainfall sequence, during which there has been an increase in the frequency of the driest winter-weather patterns and a reduction in the frequency of various wetter-winter patterns (Charles, Bates and Hughes 1999; and Steve Charles July 2007, personal communication). An 11 per cent reduction in mean rainfall is predicted for the region by the middle of the $21^{\text {st }}$ century compared to the recent (post-1975) average. Using a rainfall-runoff model of Stirling Dam, researchers have predicted that the impact of an 11 per cent reduction in rainfall will be a 31 per cent reduction in streamflows in the period 2042-62 compared to the period 1982-2002. However, there is some uncertainty in the predicted outcome because of uncertainty regarding the impact of climate change on evapotranspiration. If potential evaporation increases by 10 per cent under a warmer climate regime, then the predicted streamflow reduction is $41 \%$ (Berti et al. 2004; Bari et al. 2005). These predicted changes represent expectations 50 years from now.

In its source-development planning, the Water Corporation has adopted the use of a recent historical sequence, which was initiated in a major planning document (Water Corporation 2005) when all system yields were expressed for two climate-change scenarios; one being the post-1975 sequence and the other a more pessimistic scenario represented by the post-1997 sequence (Water Corporation 2005). In response to the extreme weather conditions experienced in 2006, which saw the lowest winter inflows on record, the Water Corporation has revised its estimates of system yield for planning purposes and now uses the climate average since 2001, including 2006. Inflows in the winter of 2000 were among the largest in recent history, and if the ruler-and-pen approach included the year 2000, the mean system yield would be $28 \%$ higher than for the '2001-06' scenario. In fact, the mean system yield for the 2000-06 scenario is similar to the mean system yield for 2050 predicted by the IOCI models. 
In the analysis provided in this paper, four system yield scenarios are presented. These are, in order of decreasing system yield, the 1975-2006 climate sequence, the 2000-06 sequence, the IOCI worst-case scenario, and the Water Corporation's current planning yield, based on the 2001-06 climate sequence.

\section{The effect of climate uncertainty on the urban water balance in Western Australia}

It is difficult to tell a simple story of the water-balance situation in Western Australia because of inconsistency between the governing agencies. On the demand side, the reality is that water is too cheap and demand is too high; and even considering the fact that consumers are on two-day per week sprinkler restrictions, unrestricted per-capita urban demand would probably be lower than current demand if price signals were corrected. ${ }^{2}$ On the supply side, one of the major sources of water for Perth, the Gnangara Mound, ${ }^{3}$ is in a serious state of degradation, and the Department of Water has been found by the Environmental Protection Authority to be in breach of Ministerial conditions regarding groundwater levels that were put in place to protect water-dependent ecosystems (Environmental Protection Authority of Western Australia 2007a and 2007b). The Department of Water (Department of Water 2007) has adopted the position that groundwater decline on the Mound is largely due to climate change (and therefore not their fault), while at the same time the amount of water allocated from the Mound in recent years has been allowed to increase to compensate for the climate-change impacts on surface-water reserves. That is, one of the key responses to the recent water shortages in Perth has been to mine the Gnangara Mound, rather than to reduce allocations in response to a drying climate. The Gnangara story is more complex again, because the Water Corporation is the highest-value user on the Mound and only represents 48 per cent of consumptive uses (Marsden Jacob 2006). With stronger governing institutions the amount of water allocated to the Water Corporation in recent years may well have increased, but in lieu of other consumptive uses rather than environmental uses.

The focus of this paper is on the decision-making of the water utility; and therefore, rather than focus on the optimal resolution to the above issues from a social point of view, the approach taken is to use the planning context faced

\footnotetext{
2 According to simulations from a model of household water demand reported in Brennan (2006).

3 The Gnangara Mound is a system of four aquifers underlying the north metropolitan and peri-urban area of Perth and is the largest single source of water for urban supply, as well as a major supplier of water for irrigation of fresh produce supplied to the Perth market.
} 
by the Water Corporation. ${ }^{4}$

The mean water-balance situation, given current institutional arrangements, is shown in Table 1 for the four climate scenarios discussed in the previous section as well as the complete (post-1911) historical record. The data in this table reflect average system yield and provide a simple exposition of the impact of climate-change assumptions on system yield and the planning deficit; hence the pressure for early augmentation. Note that the difference in system yield between the best- and worst-case climate assumptions in Table 1 is 60GL, which is a large amount of water by urban planning standards - for example, the capacity of the desalination plant at Kwinana is 45GL.

The investment in the first desalination plant, at Kwinana, was prompted by the acknowledgement that the complete historical sequence was no longer relevant for planning purposes. Analysis by the IOCI had shown a dramatic change in weather in the post-1975 sequence and the difference in yield between historic and post-1975 climate has a dramatic impact on yield. ${ }^{5}$ In the absence of this first desalination plant, urban supply was insufficient to meet projected 2007 demand for all scenarios except the post-1975 climate. The additional 45GL provided by the investment in desalination at Kwinana has provided sufficient (average) capacity to meet 2007 demand levels for all climate scenarios. However, by 2010 demand growth would be sufficient to cause a significant deficit in capacity under the six-year climate scenario. This climate scenario is necessary to justify the current decision to construct a second desalination plant to augment water supply in 2011. If the IOCI predictions are taken to be the 'best science' relating to the matter, there is no justification for augmentation in $2011 .^{6}$

\section{System reliability and the effect of climate-change assumptions}

The use of mean capacity estimates does not reflect the short-term water situation associated with below-mean dam storage levels, which elevates the risk of system failure in the short-to-medium term and is arguably the main driver of recent investments in desalination in Australia. Neither does it assess the risk of dam spills that can occur with a sequence of wet years. A system model was developed

\footnotetext{
${ }^{4}$ The current allocation rule for Gnangara groundwater, which allocates water above historical levels on a sliding scale according to dam reserves, is assumed to be in place. Whilst a draft resolution to allocation issues on Gnangara Mound is expected to be produced by 2009 (Department of Water 2008), if seasonal trade is institutionalised then a market-based solution may show the same pattern of urban water use as the current sliding-scale rule.

${ }^{5}$ The magnitude of this impact led to the so-called water crisis of the drought year 2001. Five years earlier, the Water Corporation had issued a planning document that declared that existing source developments were sufficient water for the foreseeable future (Stokes et al. 1995). In that document, the issue of climate change was mentioned but not factored into the analysis. The ultra-conservative approach now being taken by the Water Corporation may reflect this experience.

6 There is a slight deficit for the worst-case scenario, but these climate forecasts are expected to represent yield in 2050, with a gradual decline from the experience from the past two decades.
} 
to assess the risks associated with timing of investment in the second (Binningup) desalination plant proposed for Western Australia under different climate-change assumptions. Inputs to the model are an assumed probability-distribution of catchment yields (representing each climate scenario), projected urban demand and availability of water from groundwater sources (both based on existing institutional arrangements). The model tracks dam storage levels over the next 10 years and measures the frequency of dam spills and of urban-supply restrictions (triggered by low storage levels). Each scenario is analysed from 1000 random sequences of weather patterns, drawn from the probability distribution for that climate scenario. The detail of the simulation model is described in Brennan (2008).

\section{Table 1: Average water-balance situation for a range of climate scenarios}

\begin{tabular}{|c|c|c|c|c|c|}
\hline & \multirow[t]{3}{*}{ Historical } & & \multicolumn{2}{|c|}{ Climate scenarios: } & \multirow{3}{*}{$2001-06$} \\
\hline & & \multirow[t]{2}{*}{ 1975-2006 } & \multicolumn{2}{|c|}{$\begin{array}{l}\mathrm{IOCl} \text { prediction for } \\
2050\end{array}$} & \\
\hline & & & Baseline & Worst-case & \\
\hline Surface Water (SW) Yield GL & 316 & 184 & 127 & 109 & 96 \\
\hline Groundwater (GW) Yield GL & 105 & 137 & 164 & 165 & 165 \\
\hline Capacity prior to Kwinana desal plant & 421 & 321 & 291 & 274 & 261 \\
\hline Planning deficit 2007 prior to Kwinana desal plant & 0 & 0 & 13 & 30 & 43 \\
\hline Capacity after Kwinana desal plant & 466 & 366 & 336 & 319 & 306 \\
\hline Planning deficit 2007 & 0 & 0 & 0 & 0 & 0 \\
\hline Planning deficit 2011 & 0 & 0 & 0 & 3 & 16 \\
\hline Planning demand 2007 & 304 & 304 & 304 & 304 & 304 \\
\hline Planning demand 2011 & 322 & 322 & 322 & 322 & 322 \\
\hline
\end{tabular}

Source: Data provided by Water Corporation (Michael Loh, Personal Communication, October 2006) and Water Corporation (2005). Source of IOCI climate scenarios discussed in text.

In all of the scenarios, it is assumed that the Water Corporation's proposed new desalination plant is providing water at full capacity in the summer of $2011 / 12$. It is assumed that both desalination plants run at full capacity even when dams are full. While in reality these desalination plants would be switched off if rainfall significantly recovered from recent years, the assumption of full utilisation is useful to illustrate the extent of the potential surplus associated with desalination investment.

Results of the analysis are presented in the Tables 2 and 3. Table 2 shows the (unrestricted) demand forecast over time, and the risk of a sprinkler ban in each year for each climate scenario. As the climate assumptions become more conservative, the risk of a sprinkler ban increases. For all but the driest climate scenario, the risk of a sprinkler ban is already improving in the period prior to 2011. This suggests that the system reliability is in a state of recovery from the low dam reserves of 150GL at the end of the 2007 summer, due to the boost in supply provided by the Kwinana desalination plant. This confirms the average water-balance analysis presented in Table 1 - water in 2011 is not in a net-deficit 
situation for these climate scenarios. In contrast, for the most conservative climate scenario, the risk of sprinkler bans increases over the period prior 2011. The augmentation of supply reduces the risk of a sprinkler ban down to 3.4 per cent for this scenario in 2010/11. This would not be considered a very high risk in most capital cities for Australia; for example, planning for augmentation is usually done on a sprinkler-ban risk tolerance of one year in 25 (ACTEW 2004). However, in Western Australia planning is based on a one in 200 tolerance to the risk of sprinkler bans.

Also shown in Table 2 is average dam storage level, as measured at the end of winter (October), for each climate scenario. The simulation begins at the start of winter 2007 and thus has had two winters by the end of October 2008. There is already a substantial difference in end-of-winter storage levels for all scenarios. Compared to the actual storage level of 220GL at the end of October 2006, some recovery of dam storage levels is expected even for the most conservative of climate scenarios by winter 2008 . However, there is already a large divergence in recovery of dam reserves by 2008 and this divergence increases over time. Expected end-of-winter dam levels for the most conservative climate scenario remain stagnant (and combined with growing demand imply a deteriorating reliability). There is a boost to dam storage levels in all scenarios following supply augmentation in 2011, because the new desalination plant leads to a reduction in the drawdown of dams. For the 1975-2006 climate scenario, dam storage levels approach capacity over the simulation period.

Table 3 presents the analysis of the risk of 'dams running over top'. First, the risk of winter spills occurring is measured. Dams inevitably spill in high-flow years if they have a high inflow-to-storage ratio, and spills from the two dams in the Perth metropolitan system (Churchman and Stirling) that have high inflow-to-storage ratios were not included in the measures shown here. The risk of winter spills shows the risk that one of the other dams will be full enough to spill in a high-flow winter. In many cases these spills are not very substantial; so, in order to gauge events that involve serious loss of water (and would raise the question as to why the desalination plant is still running), the risk of spills exceeding 10GL was also calculated.

The risk of winter spills is very high for the 1975-2006 climate, and is exacerbated after 2011 with the introduction of the second desalination plant. In 2012, dams are expected to spill in 66 per cent of years. For the 2000-06 climate scenario, the risk of dam spillage in the near future is 6-7 per cent, but it increases to 27 per cent in 2012 following the accumulation of surface water once the second desalination plant is in use. For the IOCI worst-case climate scenario, the risk of dam spillage is substantially lower. For the Water Corporation's planning scenario (2001-06 climate) there is virtually no risk of dams spilling because system yield is so low. 
Table 2: Simulated water availability under different climate scenarios assuming second desalination plant arrives in 2011/12.

\begin{tabular}{|c|c|c|c|c|c|c|c|c|c|}
\hline & $2007 / 08$ & $2008 / 09$ & $2009 / 10$ & $2010 / 11$ & $2011 / 12$ & $2012 / 13$ & $2013 / 14$ & $2014 / 15$ & $2015 / 16$ \\
\hline Demand & 296.23 & 301.59 & 307.23 & 312.54 & 316.63 & 321.46 & 326.11 & 330.86 & 335.59 \\
\hline \multicolumn{10}{|c|}{ Calculated risk of a sprinkler ban: } \\
\hline $\begin{array}{l}1975-2006 \\
\text { climate }\end{array}$ & $0.9 \%$ & $0.5 \%$ & $0.2 \%$ & $0.2 \%$ & $0.0 \%$ & $0.0 \%$ & $0.0 \%$ & $0.0 \%$ & $0.0 \%$ \\
\hline 2000-06 climate & $2.8 \%$ & $2.7 \%$ & $1.9 \%$ & $1.2 \%$ & $0.1 \%$ & $0.1 \%$ & $0.0 \%$ & $0.0 \%$ & $0.0 \%$ \\
\hline $\begin{array}{l}\text { IOCI worst-case } \\
\text { climate }\end{array}$ & $5.1 \%$ & $5.4 \%$ & $4.3 \%$ & $4.4 \%$ & $0.9 \%$ & $0.0 \%$ & $0.1 \%$ & $0.0 \%$ & $0.1 \%$ \\
\hline 2001-06 climate & $10.1 \%$ & $12.4 \%$ & $14.0 \%$ & $16.2 \%$ & $3.4 \%$ & $0.8 \%$ & $1.0 \%$ & $0.8 \%$ & $1.4 \%$ \\
\hline \multicolumn{10}{|l|}{ October storage } \\
\hline $\begin{array}{l}\text { 1975-2006 } \\
\text { climate }\end{array}$ & 395.50 & 437.38 & 471.86 & 499.92 & 548.65 & 584.60 & 605.20 & 622.03 & 633.95 \\
\hline 2000-06 climate & 316.9 & 333.1 & 344.4 & 351.0 & 391.3 & 420.0 & 434.4 & 446.2 & 452.8 \\
\hline $\begin{array}{l}\mathrm{IOCI} \text { worst-case } \\
\text { climate }\end{array}$ & 284.27 & 291.76 & 295.92 & 296.22 & 331.36 & 352.66 & 358.68 & 362.20 & 361.13 \\
\hline 2001-06 climate & 245.75 & 245.52 & 244.90 & 242.27 & 272.31 & 288.20 & 289.36 & 288.05 & 283.39 \\
\hline
\end{tabular}

Table 3: Simulated risk of dam spills assuming second desalination plant arrives in 2011/12.

\begin{tabular}{|c|c|c|c|c|c|c|c|c|c|}
\hline & $2007 / 08$ & $2008 / 09$ & $2009 / 10$ & $2010 / 11$ & $2011 / 12$ & $2012 / 13$ & $2013 / 14$ & $2014 / 15$ & $2015 / 16$ \\
\hline \multicolumn{10}{|l|}{$\begin{array}{l}\text { Risk of winter } \\
\text { spills }\end{array}$} \\
\hline $\begin{array}{l}\text { 1975-2006 } \\
\text { climate }\end{array}$ & $31 \%$ & $37 \%$ & $41 \%$ & $45 \%$ & $62 \%$ & $66 \%$ & $62 \%$ & $63 \%$ & $61 \%$ \\
\hline 2000-06 climate & $6 \%$ & $6 \%$ & $7 \%$ & $9 \%$ & $20 \%$ & $27 \%$ & $26 \%$ & $26 \%$ & $23 \%$ \\
\hline $\begin{array}{l}\mathrm{IOCI} \text { worst-case } \\
\text { climate }\end{array}$ & $1 \%$ & $1 \%$ & $2 \%$ & $2 \%$ & $5 \%$ & $7 \%$ & $8 \%$ & $8 \%$ & $7 \%$ \\
\hline 2001-06 climate & $0.1 \%$ & $0.0 \%$ & $0.0 \%$ & $0.0 \%$ & $0.3 \%$ & $0.5 \%$ & $0.8 \%$ & $0.2 \%$ & $0.0 \%$ \\
\hline \multicolumn{10}{|l|}{$\begin{array}{l}\text { Risk of Spills > } \\
\text { 10GL }\end{array}$} \\
\hline $\begin{array}{l}1975-2006 \\
\text { climate }\end{array}$ & $16 \%$ & $21 \%$ & $28 \%$ & $32 \%$ & $45 \%$ & $54 \%$ & $52 \%$ & $53 \%$ & $53 \%$ \\
\hline 2000-06 climate & $1 \%$ & $1 \%$ & $2 \%$ & $2 \%$ & $6 \%$ & $8 \%$ & $10 \%$ & $11 \%$ & $10 \%$ \\
\hline $\begin{array}{l}\text { IOCI worst-case } \\
\text { climate }\end{array}$ & $0 \%$ & $0 \%$ & $0 \%$ & $0 \%$ & $1 \%$ & $1 \%$ & $2 \%$ & $1 \%$ & $2 \%$ \\
\hline 2001-06 climate & $0.0 \%$ & $0.0 \%$ & $0.0 \%$ & $0.0 \%$ & $0.0 \%$ & $0.1 \%$ & $0.0 \%$ & $0.0 \%$ & $0.0 \%$ \\
\hline \multicolumn{10}{|l|}{ Mean Spills** } \\
\hline $\begin{array}{l}\text { 1975-2006 } \\
\text { climate }\end{array}$ & 5.09 & 7.86 & 12.05 & 14.72 & 27.29 & 34.58 & 35.51 & 37.00 & 36.49 \\
\hline 2000-06 climate & 0.33 & 0.44 & 0.60 & 0.60 & 1.71 & 2.42 & 2.99 & 3.00 & 3.00 \\
\hline $\begin{array}{l}\text { IOCI worst-case } \\
\text { climate }\end{array}$ & 0.05 & 0.05 & 0.12 & 0.05 & 0.22 & 0.33 & 0.48 & 0.41 & 0.35 \\
\hline 2001-06 climate & 0.00 & 0.00 & 0.00 & 0.00 & 0.00 & 0.02 & 0.01 & 0.00 & 0.00 \\
\hline
\end{tabular}


The high risk of dam spills for the 1975-2006 climate also corresponds to a high risk of spills that are of a large volume. If the supply augmentation occurs in 2011 , the risk of dams spilling more than 10GL of water in 2002 is 54 per cent. In the case of the 2000-06 climate, the risk of dam spills exceeding 10GL in 2012 is 8 per cent. For the drier climate scenarios the risk is insignificant.

A comparison of the 2000-06 climate scenario with the 2001-06 scenario highlights the current decision-making dilemma regarding climate uncertainty. Adding the relatively wet year of 2000 has a substantial impact on the apparent desirability of supply augmentation. The 2001-06 climate scenario implies that the probability of a sprinkler ban is 16 per cent in 2010, prior to the introduction of the new desalination plant. In contrast, the 2000-06 scenario implies that there is little risk of a sprinkler ban even before the plant is introduced, and the risk of dams spilling more than 10GL per annum is 10 per cent by 2013. Using the 'ruler and pen' approach to climate forecasting means that our estimate of whether we will be 'rooned' by drought or 'rooned' by desalination obsolescence all hinges on whether or not we include 2000 in the time series.

\section{Implications for long-run marginal cost}

Climate change will change the long-run cost of any given amount of water supply.

The Western Australian economic regulator has adopted the perturbation or 'Turvey' approach to the calculation of long-run marginal cost (Economic Regulatory Authority 2005). The approach accounts for the nature of water-supply infrastructure, including lumpiness in augmentation and jointness in integration, as well as the inevitability of supply expansion. Turvey (1976) suggested that long-run marginal cost for water is a dynamic cost which relates to the effect of demand growth on the rate at which the water-supply system must expand. The perturbation method works out the capital-expenditure program required to meet forecast growth in demand and compares it to a second capital-expenditure program associated with a smaller (or larger) forecast pattern of demand. Long-run marginal cost is calculated as the difference in the net present value of costs, divided by the difference in net present value of quantity demanded for the two scenarios. The Turvey approach was used to assess the potential impact of climate assumptions on the calculated LRMC.

For this exercise, the baseline forecast demand was based on the Water Corporation's per-capita demand assumption and assumed to grow with population growth. Growth assumptions in the medium term were based on demographic forecasts (Western Australian Planning Commission 2005). Beyond 2031, growth was assumed to continue at the same growth rate as in 2031. The calculations start in 2011, when the first feasible capital expenditure can occur, which is assumed be the desalination plant at a cost of $\$ 955$ billion (Western 
Australian Government 2007). Subsequent augmentation is based on the source developments ${ }^{7}$ costed in Water Corporation (2005), with costs measured in 2011 dollars for consistency. A 100-year capital-expenditure program was examined, with desalination as the augmentation source after available conventional sources have been exhausted. The operating cost of desalination is assumed to be $\$ 1.04$ per $\mathrm{kL}$, which is significantly higher than the (Water Corporation 2005) estimate of 40-44 cents per $\mathrm{kL}$, not just because of sharp increases in nominal energy prices over the time period, but also because of the fact that the cost quote for the Kwinana plant does not allow for the cost of renewable energy. ${ }^{8}$ A discount rate of 6 per cent was assumed.

Results are presented in Table 4. Compared to a 1975-2006 climate scenario, which provides an LRMC of $\$ 0.78$ per $\mathrm{kL}$, the LRMC associated with the Water Corporation's 2001-06 climate scenario is $\$ 2.19$ per kL.

These costs can be compared with the prices set recently by the economic regulator in Western Australia (Economic Regulatory Authority 2008). These prices are based on an earlier price determination (Economic Regulatory Authority 2005) that had been adjusted for inflation. The previous enquiry based the LRMC calculation on assumptions that are now out of date (including the assumption that the South West Yarragadee would go ahead ${ }^{9}$ and yield more than 45GL, and the assumption that climate would be somewhere between post-1975 and post-1997 historical means ${ }^{10}$ ).

Projected nominal urban-water prices for 2011 are shown in Figure 1. Because of the inclining block tariff structure it is necessary to overlay the graph with a depiction of the pattern of household consumption. On the right-hand axis is the cumulative distribution of household consumption, indicating the proportion of households whose consumption is less than, or equal to, the annual volume shown on the horizontal axis. Around 93 per cent of households consume 550kL or less, and are therefore subject to prices of $\$ 1.03$ per $\mathrm{kL}$ or less at the margin. This is less than half the long-run cost associated with a climate-change assumption adopted by the Water Corporation to justify its capital expenditure on another desalination plant.

\footnotetext{
7 Specifically the Wellington Dam upgrade; Brunswick Dam; Eglinton Yanchep and Gingin borefields; and managed aquifer recharge.

8 The deal involving purchase of power from a wind farm was made after the electricity had already sold the green component of its energy as renewable-energy certificates to the electricity utility (Tony Stewart, Office of Energy, personal communication, June 2007).

9 The Water Corporation's preferred supply augmentation was to tap the Yarragadee aquifer in the south-west of the state and connect it to the metropolitan infrastructure using a $105 \mathrm{~km}$ pipeline. The environmental-approval processes for this proposal took five years and there was considerable controversy both in the scientific community and in the public, culminating in a decision by the WA Premier to not allow development of the proposal.

${ }^{10}$ (Greg Watkinson, personal communication, 2006). The post-1997 yield was previously the worst-case climate scenario (Water Corporation 2005) and mean yields are similar to the mean yield for the IOCI baseline forecast.
} 
Table 4: Calculation of long-run marginal cost of bulk water supply for different climate assumptions, in 2011 dollar-terms

\begin{tabular}{|c|c|c|c|c|}
\hline & & \multicolumn{3}{|c|}{ Climate scenario } \\
\hline & & 1975-2006 & $\mathrm{IOCI}$ baseline & 2001-06 (WC) \\
\hline Increment, 15kL/capita & $\begin{array}{l}\text { Additional } \\
\text { Capital } \\
\text { expenditure } \\
\text { \$m }\end{array}$ & 280 & 829 & 899 \\
\hline \multirow[t]{3}{*}{ NPV of additional water $611 \mathrm{GL}$} & $\begin{array}{l}\text { Additional } \\
\text { Operating } \\
\text { expenditure } \\
\$ \mathrm{~m}\end{array}$ & 243 & 416 & 527 \\
\hline & $\begin{array}{l}\text { Total } \\
\text { Additional } \\
\text { Cost } \$ \mathrm{~m}\end{array}$ & 523 & 1,245 & 1,426 \\
\hline & $\begin{array}{l}\text { Marginal } \\
\text { cost } \$ / k L\end{array}$ & 0.86 & 2.04 & 2.33 \\
\hline Decrement, $15 \mathrm{~kL} /$ capita & $\begin{array}{l}\text { Saved } \\
\text { Capital } \\
\text { expenditure } \\
\$ \mathrm{~m}\end{array}$ & 285 & 623 & 689 \\
\hline \multirow[t]{3}{*}{ NPV of saved water $611 \mathrm{GL}$} & $\begin{array}{l}\text { Saved } \\
\text { Operating } \\
\text { expenditure } \\
\$ \mathrm{~m}\end{array}$ & 147 & 375 & 559 \\
\hline & $\begin{array}{l}\text { Total Saved } \\
\text { Cost } \$ \mathrm{~m}\end{array}$ & 432 & 998 & 1248 \\
\hline & $\begin{array}{l}\text { Marginal } \\
\text { cost } \$ / k L\end{array}$ & 0.71 & 1.63 & 2.04 \\
\hline Long-Run Marginal Cost & & 0.78 & 1.83 & 2.19 \\
\hline
\end{tabular}

Figure 1: Projected tariff structure for 2011 and distribution of household consumption

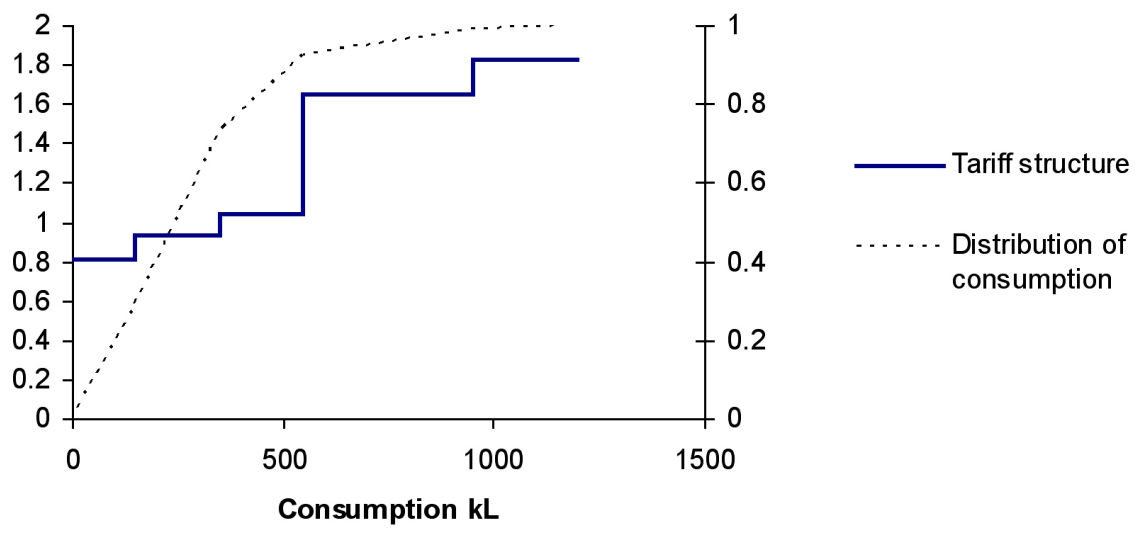


The establishment of correct price incentives will therefore require a doubling of prices. Even if consumer demand is relatively price inelastic, a significant impact on per-capita consumption is likely. For example, it is well established that demand is more inelastic for indoor uses, with indoor (or winter) elasticity generally less than -0.05 , and outdoor demand elasticity can be higher, such that measures of aggregate household demand elasticity have been reported to be around -.3 to -0.4 (NERA 2001; Arbues et al. 2003; Dalhuisen et al. 2003). About half of water is used for indoor use in Perth. Using an indoor elasticity of -0.05 and an outdoor elasticity of -0.2 , the calculated impact of a doubling of prices is 15 per cent or $23 \mathrm{~kL}$ per capita. ${ }^{11}$

\section{Impact on the risk of a sprinkler ban of aligning prices with climate expectations}

Thus significantly lower demand would be expected if prices were aligned with the LRMC associated with Water Corporation climate expectations. The effect of lower per capita demand on the risk of a sprinkler ban, for the Water Corporation's climate forecast, is shown in Table 6. Even if higher prices were only able to reduce per-capita demand from $155 \mathrm{~kL}$ to $150 \mathrm{~kL}$, the risk of a sprinkler ban in 2010/11 could be reduced substantially from 16.2 per cent to 3.9 per cent. Since the price response to a correction in pricing signals is likely to result in a more significant demand reduction, the risk of a sprinkler ban would be reduced more substantially. Thus, even in the worst of the worst-case climate scenarios, the proposed urgency of the next source would be questioned if prices were adjusted to reflect LRMC.

Table 6: Impact of per-capita demand on the risk of a sprinkler ban, for worst-case (2001-06) climate scenario

\begin{tabular}{crrrrr}
\hline $\begin{array}{c}\text { Assumed } \\
\text { per-capita } \\
\text { demand }\end{array}$ & $\mathbf{2 0 0 7 / 8}$ & $\mathbf{2 0 0 8 / 9}$ & $\mathbf{2 0 0 9 / 1 0}$ & $\mathbf{2 0 1 0 / 1 1}$ & $\mathbf{2 0 1 1 / 1 2}$ \\
\hline 155 & $10.10 \%$ & $10.90 \%$ & $10.20 \%$ & $10.60 \%$ & $2.40 \%$ \\
150 & $5.50 \%$ & $6.30 \%$ & $4.10 \%$ & $3.90 \%$ & $0.70 \%$ \\
145 & $2.70 \%$ & $2.80 \%$ & $1.60 \%$ & $0.50 \%$ & $0.00 \%$ \\
140 & $1.00 \%$ & $1.40 \%$ & $0.50 \%$ & $0.10 \%$ & $0.00 \%$ \\
135 & $0.50 \%$ & $0.30 \%$ & $0.00 \%$ & $0.10 \%$ & $0.00 \%$ \\
\hline
\end{tabular}

\section{Conclusions}

The threat of climate change is a serious concern for water-supply planners, but given the uncertainty surrounding climate forecasts, there is an opportunity for pessimistic interpretation of future climate to justify larger and earlier investment in desalination technology. While there is a lot of uncertainty surrounding climate-change science, one would expect that the body of knowledge that now exists could produce a more rigorous estimate of water-system yield than an

${ }^{11}\left(0.05^{*} 50 \%+0.3^{*} 50 \%\right)^{*} 100 \%=17.5 \% * 155=27.175$ 
arbitrary selection of recent years' data. Since the desalination investments being made across the country are typically of the order of $\$ 1$ billion per plant, the value of information regarding climate forecasts, and arguably the benefit of investing more research in this area, is high.

Given the unscientific manner being used by water-supply planners to predict the climate, the justification for investment is flimsy, especially when the other side of the probably distribution is taken into account. It was demonstrated here that the inclusion of the year 2000 in the time series used to calculate mean system yield can turn Hanrahan's lament on its head. Inclusion of one more year in the time series presently used for planning completely removes the risk of a sprinkler ban and the justification for the proposed augmentation in 2011 and results in a significant risk that the government and water-supply planners could be embarrassed by the opposite problem of dams spilling shortly after a very expensive water-manufacturing plant has been constructed. Worse still, utilities may be committed to keep paying to operate the desalination plant if take-or-pay arrangements have been contracted under public-private-partnership arrangements.

There is good potential for reining in the temptation to overestimate the impact of climate change on system yield through effective economic management. If future system yield is really as dire as the water planners predict, the implications for long-run marginal cost on prices are likely to have significant impact on demand and on the need for investment in desalination. The example shown here demonstrates that if the Economic Regulatory Authority adopted the same water forecast as the Water Corporation in Western Australia and had enough power to force proper LRMC pricing, the current construction of the desalination plant in Western Australia could be at least postponed.

\section{References}

Arbues, F., Garcia-Valinas, M. and Martinez-Espineira, R. 2003, 'Estimation of residential water demand: a state of the art review', Journal of Socio-Economics 32: 61-102.

ACTEW Corporation Ltd 2004, 'Future water options for the ACT region in the $21^{\text {st }}$ Century - An assessment of the need to increase the ACT's water storage', ACTEW Corporation, Canberra, at: <http://www.actew.com.au/ futurewateroptions/documents/assessmentReport.pdf $>$ Accessed 10 January 2008.

Bari, M., Berti, M., Charles, S., Hauck, E. and Pearcey M. 2005, 'Modelling of streamflow reduction due to climate change in Western Australia - a case study', paper presented at the International Congress on Modelling and Simulation MODSIM05, 12-15 December. Available at: 
<http://mssanz.org.au/modsim05/papers/bari.pdf > Accessed 20 July 2007.

Berti, M., Bari, M., Charles, S. and Hauck, E. 2004, 'Climate change, catchment runoff and risks to water supply in the South West of Western Australia', Department of Environment.

Brennan, D. 2006, 'Efficiency and equity implications of Perth's inclining block urban water tariffs', presented at the $50^{\text {th }}$ Australian Agricultural and Resource Economics Society Annual Conference, Sydney, February 2006.

Brennan (2008), 'Desalination, climate change and Hanrahan's lament', Paper presented at the 52nd Conference of the Australian Agricultural and Resource Economics Society, Canberra, 6-8th February, 2008.

Charles, S., Bates, B. and Hughes J. 1999, 'A spatiotemporal model for downscaling precipitation occurrence and amounts', Journal of Geophysical Research 104(D24) 31: 657ff.

Cooley, H., Gleick, P. and Wolf, G. 2006, 'Desalination, with a grain of salt: A Californian Perspective', Pacific Institute, Oakland, California, at $<222$.pacinst.org/reports/desalination> Accessed May 2007.

Dalhuisen, J., Florax, R., de Groot, H. and Nijkamp P. 2003, 'Price and income elasticities of residential water demand: a meta-analysis', Land Economics 79: 292-308.

Department of Sustainability and the Environment 2007, 'Our water, our future: The next stage of the government's water plan', Victorian Government, at <http://www.ourwater.vic.gov.au/pdf/plan/DSEWaterReport.pdf> Accessed July 2007.

Department of Water 2007, 'Environmental management of groundwater abstraction from the Gnangara Mound June 2004-5', Annual Compliance Report to the Environmental Protection Authority, Perth, WA. At $<$ http://portal.water.wa.gov.au/portal/page/portal/WaterManagement/ Groundwater/Gnangara/Content/Gnangara_Compliance_2004-05.pdf>

Department of Water 2008, 'GSS: Gnangara sustainability strategy, Project briefing', at: < http://portal.water.wa.gov.au/portal/page/portal/ gss/GnangaraSustainability Strategy > Accessed 27 January 2008.

Economic Regulatory Authority of Western Australia 2005, 'Final report: Inquiry into urban water and wastewater pricing', Economic Regulatory Authority, Perth.

Economic Regulatory Authority 2008, 'Final report: Inquiry on Water Corporation's tariffs', 16 January 2008. 
Environmental Protection Authority 2007a, 'Report on Waters and River Commission's Environmental management of groundwater abstraction from the Gnangara Mound June 2004-5', Annual Compliance Report, Bulletin 1252, Perth, Western Australia, at: <http://www.epa.wa.gov.au/docs/2477_EPABull1252_S48.pdf>

Environmental Protection Authority 2007b, 'Environmental management of groundwater abstraction from the Gnangara Mound, July 2004-June 2005', Annual Compliance Report, Bulletin 1252, at: <http://www.epa.wa.gov.au/docs/2477_EPABull1252_S48.pdf>

Marsden Jacob Associates 2006, 'Identification of Economic Values Associated with the Groundwater of the Gnangara Mound', report prepared for the Department of Water, WA.

National Economic Research Associates (NERA) 2001, 'A review of Melbourne's water tariffs, A report for the Department of Natural Resources and Environment', Sydney, October.

O' Brien, J. 1921 'Said Hanrahan', Around the Boree Log and Other Verses, Mercier Press/Marino Books, February 1990.

Pittock, B. (Ed.) 2003, 'Climate change - An Australian Guide to the Science and Potential Impacts', Australian Greenhouse Office, at: http://www.greenhouse.gov.au/science/guide/index.html

Stokes, R., Beckwith, J., Pound, I., Stone, R., Coghlan, P. and Ng, R. 1995, 'Perth's water future - A water strategy for Perth and Mandurah to 2021 (with focus on 2010)', Water Corporation of Western Australia, at: $<$ www.watercorporation.com.au/_files/PublicationsRegister/12/ perth_water_future.pdf $>$ Accessed 12 January 2008.

Turvey, R. 1976, 'Analyzing the marginal cost of water supply', Land Economics 52(2): 158-68.

Water Corporation 2005, 'Source Development Plan', Water Corporation, Leederville.

Western Australian Planning Commission 2005, 'Western Australia Tomorrow', population report number 6 .

Western Australian Government 2007, 'Second desalination plant to be State's next major water source', Alan Carpenter Media release 15 May 2007, at: http://www.mediastatements.wa.gov.au/media/media.nsf 